ARTICLE

\title{
"Quilt", aesthetic experience and autobiographical narrative: future teachers and the art of listening
}

\author{
Margaréte May Berkenbroc-Rosito a \\ Juliana Paiva Pereira de Souza ${ }^{b}$ \\ Sidclay Bezerra Souza ${ }^{c}$
}

\section{Abstract}

The purpose of this paper is to analyze "Quilt", a formative and investigative device, methodology, and epistemology developed by Berkenbrock-Rosito and used since 2001. In this study, we present Quilt, a device intended to contribute to teacher education through the production of written, pictorial, and oral (auto) biographical narratives, in the Pedagogy Course of a university private area on the east side of the city of São Paulo. The methodology included a contextual questionnaire featuring questions on what "Quilt" participants liked and did not like about the experience. Data shows that "Quilt" can be considered a valuable methodology to listen to subjects, which postulates the existence of an aesthetic dimension in the constitution of one's teaching identity.

Keywords: Quilt. Aesthetic Experience. Teacher Education.

\section{Introduction}

Vertiginously fast transformations can be considered a defining cultural trait of the societal ethos of our day and age. Along with this speed comes the feeling that everything is consumed ravenously: artistic objects and human beings alike are regarded and valued as short-lived merchandise. The fleeting values shaped by such rampant production and consumerism generate discomfort and tend to distance subjects from the need to reflect upon their choices and decisions.

\footnotetext{
a Universidade Cidade de São Paulo, São Paulo, SP, Brasil.

b Serviço Nacional de Aprendizagem Comercial, São Paulo, SP, Brasil.

c Universidad Católica del Maule, Talca, Chile.
} 
A prevailing scientific and materialistic conception presumes to account for the meaning of the universe and of human existence based almost solely to reason, thus privileging experimental knowledge and, subsequently, emphasizing instrumental reasoning over other aspects of knowledge. Instrumental reasoning tends to favor cognitive development as a quality indicator, thus overlooking the emotions and feelings that are an integral part of a person's global development, and also valid knowledge sources. These bias compromises subjects' autonomy and emancipation.

Conversely, we regard the emotions that result from aesthetical experiences as an epistemological factor of subjects' narrative processes, one that promotes the development of autonomy and emancipation of Teacher Education students and future teachers. To this end, the strategies and stages comprised in the investigative and formative device "Quilt" epistemologically rouse emotions and feelings as a result of its unique aesthetic experience. Thus, we believe that aesthetic curiosity can serve as the starting point on a subject's journey towards epistemological curiosity, knowledge construction, and knowledge creation.

To Freire (1996), educational understanding involves a process in which the subject builds their own political, ideological, ethical, moral, and aesthetical values, as well as their own power, as they experience autonomy in the development of their ability to decide and to make choices; these moments become movements and configure one's experience of what it means to be a subject.

The (auto)biographic narrative process develops one's ability to make choices and decisions about what to tell and what to keep to oneself. Thus, narrating one's own formative journey becomes a way to promote the development of responsibility towards oneself, others, and the world, as well as a broader outlook on life.

The object of research based on (auto)biographic narratives is experience. Our particular focus is aesthetical experience, which is simultaneously that which astonishes, and a reflection on this astonishing fact/object/experience/etc. This movement of thinking about something leads to Aesthetical Education, to an Education of the senses that interconnects self-knowledge, art, and sensibility, which we regard as a necessary triangulation in formative processes that are in line with an Education committed to subject autonomy and emancipation.

Is initial teacher Education nothing but aesthetical? We believe that all experiences have political, ideological, ethical, moral, aesthetical, and power-related 
dimensions. In Freire's (1996) words, these dimensions are invisible threads connecting the development process of subjects' autonomy and emancipation, and they become visible in the ways those subjects think, feel, and act - in their practices.

The purpose of this study is examining the role of the aesthetical dimension on the development of subjects' autonomy, authorship, and emancipation. This specific dimension was chosen due to the fact that few attempts have been made to investigate the role of aesthetics on initial teacher education. A search for related descriptors on the Coordenação de Aperfeiçoamento de Pessoal de Nivel Superior - Capes (Coordination for the Improvement of Higher Education Personnel) thesis and dissertation database, using the following filters: knowledge area: Humanities; subarea: Education, yielded the following results: of a total of 1,736 thesis and dissertations, there were 0 entries tagged 'aesthetics and teacher identity', and 0 entries tagged 'teacher identities and quilt'.

In order to address this research gap, in this paper we reflect upon the constitution of the professional identity of future teachers in the early stages of a Teacher Education undergraduate program. Our object is the students' interaction with "Quilt", an autobiographical narrative device created by Berkenbrock-Rosito (2009) that allows participants to recover and to identify constitutive factors of a) teacher knowledge, b) teaching praxis, and c) being a teacher, thus enabling the future teachers to attribute new meanings to the roles they have played so far into their educational trajectory.

Therefore, we believe that "Quilt" contributes to the aesthetical formation of teachers who will later work in K-12 Education by enhancing their perception of subjective experiences - seen as the device involves narratives of personal, professional, and school-based situations that directly relate to how like and dislike interfere in decision-making and in one's choices.

This paper is structured as follows:

The first section presents a conceptual discussion on Aesthetics. We argue that it is possible to redefine a subject's formative journey and their understanding of its aesthetical dimension; after all, as Schiller (2002) demonstrates, all human production has an aesthetical representation that stems from an emotion that permeates one's relationship with the world. This aesthetical representation, which is inherent to all human productions, allows subjects to understand the 
specific needs of each moment of their professional Education by looking back on their formative journey and understanding narratives, as well as their aesthetical dimension.

In the following section, we argue that "Quilt" is a methodology, an epistemology, and a way of incorporating aesthetic experiences into a teacher's professional identity. To this end, we describe Quilt's dimensions and stages, how its autobiographical narratives are produced, and its goal of articulating new knowledges based on aesthetic experience, enabling its participants to form significant and contextualized conceptions.

In section three, we present the data analysis methodology. Data were collected through a contextual questionnaire answered by 46 participants and analyzed using Almeida, Flickinger and Rohden (2000) hermeneutical approach. Next, we discuss the results, showing how working with narratives can be a key factor to foster subjects' autonomy and emancipation by investing in the aesthetic dimension of formative processes. Lastly, we present our conclusions.

\section{Aesthetic possibilities in teaching praxis: from aesthetic Education to autonomy}

The relationship between knowledge, teacher, and student involves instances of both delight (like) and discontentment (dislike), as a multitude of feelings may be experienced in a classroom. The process of producing autobiographical narratives provides many an opportunity for the subject to claim their own story, to choose what to reveal to others, and to come to know themselves as a historical subject, as well as to unveil various aspects involved in their teaching knowledge, teaching praxis, and teaching identity.

Since "Quilt" participants are called to play an active role, the device can contribute to counter what Freire (1996) calls the "Banking Education model", in which the student is regarded as an empty vessel whose only role is that of a receptacle for information and knowledge transferred by a teacher. Conversely, Freire advocates that we must consider a student's knowledge; he emphasizes that "the disregard for how a student reads the world reveals an educator's elitist - and thus antidemocratic - tastes. By acting like that, the educator does not listen to his students, does not talk to them, but merely deposits communiqués into them instead." (FREIRE, 1996, p. 123). 
At the heart of "Quilt" as a formative process lies an aesthetic unveiling of feelings of delight and discontentment, in a game striving for balance; this derives from Schiller's (2002) definition of the aesthetical:

everything that can manifest as phenomena can be regarded under four aspects. Something may relate directly to our sensuous state (our physical existence and well-being); that is its physical character. Alternatively, it may relate to understanding and provide knowledge; that is its logical character. It may also relate to our will and be seen as the object of a choice made by a rational being - that is its moral character. Lastly, something may relate to the whole of our many faculties, without being an object pertaining exclusively to any of them, and that is its aesthetic character (p. 76).

Schiller's (2002) aesthetics encompasses a wide array of ideas on beauty, the reality of art, works of art, sensory perception, and feelings. His object is the very faculty of feeling - Baumgarten's Aesthetica, that is, all things related to sensibility. Schiller's sensibility is not antithetical to understanding or reason, but rather suggests that there is a dimension of reason within the sensory, a dimension open to shapes and laws. Therefore, the aesthetical is a mediation between reason and sensuousness that constantly strives for harmony between those terms, both within a person and in that person's interactions with the world. Despite possessing an inherent degree of freedom, sensibility manifestations are still tied to laws and morals. According to Schiller, sensibility emerges freely when we experience rapture and epiphanies, and it plays a part in everything that strikes us, affects us without permission; everything that manifests as like/dislike of what we read, see, hear, touch, contemplate, and also in our reactions of passion, repulse or disinterest. Schiller explains that the aesthetical is "a manner of contemplating our experiences but also life itself, as we feel it. In a word: it is at once our sensuous state and our action" (SCHILLER, 2002, p. 127).

Schiller (2002) demonstrates that beauty is as much a part of human life as its other dimensions, since it plays a part in the physical, the psychic and the spiritual, as well as on other human activities; he therefore concludes that beauty must be learned.

Thus, Schiller's aesthetic experience is the epiphany or rapture one feels in relation to daily life events. It is part of a conceptual framework that postulates the subjectivity and wholeness of a sensuous, social, political, and cultural subject. However, the importance of reflecting on the aesthetic component of like/dislike, 
beauty/ugliness is often overlooked in Education in favor of a (supposedly) more effective and practical education.

An Aesthetical Education endeavors to educate human emotions. It addresses the like/dislike, beauty/ugliness relations that play a part in all relationships and in experience in general. Santos (1995) claims that, for Schiller, the aesthetic dimension of Education manifests itself in the pedagogical project: it animates educational contents, goals, and choices on how to educate, as well as the educational spirit and the environment where educational and formative processes happen: the furniture, the building's architecture, the landscape, the relationships between participants. Lastly, an aesthetical Education also involves educating people to experience art and/or by using artistic means.

Reflecting on Aesthetical Education, Schiller (2002) also mentions the process of creating a work of art. He is adamant that this creation must envisage a work in which the material and its intended form are one and the same: it refers to "the actions of the pedagogical and political artist, who makes man into his material and his task. As this work favors the inner essence of man, the peculiarity and personality of his material must be spared." (Schiller, 2002, p. 34-35).

Schiller champions the great relevance of Aesthetical Education as the path to rouse human sensibility. A teacher's actions help introduce their students to a universe of emotions by stimulating their capacity to elaborate and recreate what they already know and to transform their reality, while respecting their singularity.

A person's life story rouses the awareness of what Josso (2007) calls "being-a-subject": gaining ownership over one's story in a continuous movement of both wanting and being able to come-to-be. Josso's interconnected sensory dimensions (embodied being, sensitive being, emotional being, affective being, cognitive being, imaginative being, bodily action being and being of willful attention) arise from questioning one's existence. We believe that every narrative features these eight dimensions.

Josso's sensitive being may be considered a direct representation of the aesthetical in relationships, given that it concentrates the expression of "all the 'pleasant' or 'unpleasant' feelings we experience in our daily lives." (JOSSO, 2007, p. 427). These feelings are experienced bodily, in relation to oneself or to other people. The affective being allows us to access the "newly-formed, preserved or broken ties connecting us to values we have either internalized unwittingly or chosen 
upon careful reflection." (JOSSO, 2007, p. 428). This dimension regulates the intensity of our stories by producing bodily records of our experiences that may cause suffering and ruptures if they are not internalized and integrated.

According to Perissé (2014), a teacher's aesthetical Education is a personal trajectory that enables a subject to broaden not only their worldview but also their senses. After arguing that knowledge cannot be effectively produced unless the act of learning is permeated by bodily sensations, Perissé asks whether a teacher's role should, like an artist's, be that of producing works that can lead others to think beyond their creation.

Perissé also stresses the importance of teachers as mediators, claiming that they must be the ones inviting students to take on a new and meaningful role. This new role may occasionally involve discontentment as well as delight, since what really matters is the process and how it can contribute to an understanding of everything that was felt and experienced. Hence, the act of learning must be regarded as a humanizing experience.

Thus, "a teacher's aesthetical Education (a far cry from pasteurized formatting) consists in enabling him to better see what he is seeing, to better hear what he is hearing, to better savor what he is savoring." (PERISSÉ, 2014, p. 53). When this comes to pass, the teacher becomes a subject of thought and feeling, enhances their self-awareness and develops the ability to perceive a veritable universe of potential and possibilities in their students. As Maturana (1998) puts it, that teacher will then allow the student to exist, to be the creator and author of their own story, and consequently to transform their reality.

In a similar vein, Adorno (2002) vehemently condemns what he deems a "pasteurization of feelings" and emphasizes how the aesthetical can enable individuals to conceive their own way of life, a way of positioning themselves derived from a subjective understanding of life and of the other. However, to Adorno, the culture industry pushes individuals to be excessively practical and irreflective, leading to a "half education" (Halbbildung) and keeping individuals from emancipating themselves from instrumental rationality. Adorno formulates a scathing critique of the reproduction of knowledge and of cultural massification, both of which he believes to serve the interests of a selected few.

Consistent with this perspective, Freire (2013) posits that a teacher's main goal should be to rouse aesthetic awareness in their students so as to avoid what he calls "castration of the epistemological awareness". He expands on the importance of 
the individual's existence and assigns the school the responsibility of a) enabling this subjective birth, and $b$ ) being a place where students can read not just words, but also contexts and the world itself.

In the same book, Freire (2013) stresses the importance of ethical responsibility to an individual's Education and argues that it is a teacher's responsibility to broaden the universe presented to their students in the classroom. Thus, he exhorts teachers to go beyond technical reading in order to promote readings of contexts and of the world itself, thereby enabling subjects to position themselves in active roles; this means that a teacher's work also involves the aesthetical.

"Quilt" participants are prompted to remember memorable school experiences. This often highlights the role played by teachers in each student's historical constitution, thus evidencing the traces left in that role. It also points to a potential teaching model that students may unwittingly try to emulate or deny. Therefore, "Quilt" offers future teachers an opportunity for historical reparation of their experiences.

As students participate in the formative and investigative device "Quilt", narrating their own story may prove to be a decisive factor in the awakening of their self-awareness.

\section{3 "Quilt": an object of study}

The specific Quilt analyzed in this study involved 46 students on their second semester of a Teacher Education undergraduate program at a private University located in the eastern area of the city of São Paulo, Brazil. It took place as part of a course on "Organizing a Teacher's Work" (March through June of 2018).

"Quilt" narratives are produced in three different dimensions (written, pictorial and oral) with specific steps and strategies. Each quilt stage and each dimension of a past or current narrative continually incorporates the thoughts and suggestions of former and current "Quilt" participants. Below we presented the "Quilt" dimensions Chart 1 of the process experienced by the participants. 
Chart 1 - "Quilt" dimensions

\begin{tabular}{|l|c|c|c|}
\hline Stage 1 & $\begin{array}{c}\text { Written Narrative } \\
\text { Describing three } \\
\text { from one's school years. }\end{array}$ & $\begin{array}{c}\text { Pictorial Narrative } \\
\text { Locating in the written } \\
\text { narratives images and } \\
\text { metaphors that can be } \\
\text { used to manufacture a quilt } \\
\text { square, then producing an } \\
\text { imagetic representation of } \\
\text { one's narrative. }\end{array}$ & $\begin{array}{c}\text { Oral Narrative } \\
\text { Telling one's story and } \\
\text { listening to someone } \\
\text { else's. }\end{array}$ \\
\hline Stage 2 & $\begin{array}{c}\text { Producing the "Life Line" } \\
\text { board. Charting hinge } \\
\text { moments. }\end{array}$ & $\begin{array}{c}\text { Taking photos to document } \\
\text { the quilt's production and } \\
\text { the finished product. }\end{array}$ & $\begin{array}{c}\text { Collectively sewing the } \\
\text { squares to make the } \\
\text { quilt. }\end{array}$ \\
\hline Stage 3 & $\begin{array}{c}\text { Watching the movie How } \\
\text { to make an American } \\
\text { Quilt and looking for } \\
\text { significant metaphors for } \\
\text { one's own life story, thus } \\
\text { completing the movie } \\
\text { narrative stage. }\end{array}$ & $\begin{array}{c}\text { Aesthetic appreciation } \\
\text { of the "Quilt". } \\
\text { Discussing and } \\
\text { exchanging thoughts } \\
\text { on its collective } \\
\text { production. }\end{array}$ \\
\hline
\end{tabular}

Source: Created by the authors (2020)

In the first stage of the written narrative, participants are asked to describe three memorable educational experiences - if they are undergraduate students, they should refer to High School, and if they are graduate students, to their undergraduate years. The strategy for this stage involves three questions designed by Berkenbrock-Rosito (2009) to promote reflection on one's relationship with knowledge: 1) What kind of student were you? 2) What sort of relationship did you have with your teacher? 3) Would you describe this relationship as one of authorship or submission?

The second written narrative stage is the production of a "Life line" board. Working with time and space categories (such as family life, school life, work life, academic life, love life, people, books, and films that have influenced geographic displacements, among other space-related categories), the participants map what Josso (2007) refers to as "hinge moments", which are memorable situations in one's personal trajectory that act as turning points and produce changes in one's worldview. The goal of mapping such moments is "to understand how subjects come to know, as well as the impact of learning in their social, professional and personal formation" (BERKENBROCK-ROSITO, 2009, p. 495).

The third written narrative stage consists of watching the movie How to make an American quilt (Mocelin Moorhouse, USA, 1995). In this stage, 
each participant's goal is to pinpoint movie scenes and metaphors that can be significantly connected to their own life story; this is the written dimension of the movie narrative stage.

For the second narrative dimension in "Quilt", participants produce pictorial narratives derived from the written ones. Participants begin by searching their written reports for images and metaphors, to which they apply the quilting strategy to produce a pictorial image of their narrative. Each participant hand-makes their square at home, then brings it to the course at a fixed date. The narratives of all participants are integrated into a single final product: the Quilt.

The final step is the oral narrative dimension. All Quilt participants sit in a circle and each person tells the story depicted in their own quilt square. After everyone has told their story and listened to everybody else's, the group sews the squares to make the quilt. Once it is finished, there is a round of aesthetic appreciation of the quilt as a work of art, which includes bringing forth and discussing participants' opinions on their individual and collective creative activity. The photographic records of the finished quilt also fall within the pictorial dimension.

The third dimension (oral narrative) takes place in the classroom, when each participant presents their quilt square (their own pictorial narrative) and reads the document containing all written narrative stages. The oral narratives enable individuals to unveil their particular story as part of the collective work and offer "Quilt" participants a chance to understand and resignify their decisions and choices. In some cases, the contemplation of one's own story is ultimately freeing and allows the subject a broader understanding of the facts.

Through an aesthetic experience, the students get to contemplate their trajectories and identify actions and facts that might echo in their own pedagogical praxis. As Freire (1996) points out, we are historical beings and this historicity directly influences how we relate to knowledge, and consequently how a teacher will facilitate their students' learning.

A narrator exerts choice as they select the contents to be presented in a narrative. Josso (2006) underscores this agency and explains that the narrator negotiates with themselves in order to decide what to share and what to keep to themselves.

Barros, Dias and Cabral (2019, p. 318) argue that "teachers must find practices and knowledge-making tactics that potentialize pedagogical action". We believe that as a methodological device, Berkenbrock-Rosito's (2009) "Quilt" works 
towards that goal by providing the conditions to allow students to choose during the creation of their self-narratives.

According to Freire (1996), aesthetics is a cornerstone of a Pedagogy of Freedom; it is critical to the development of autonomy and emancipation, because autonomy is achieved by enabling subjects to make choices and decisions. By creating the conditions for this, the teacher drives the student to take on a more active role. "Quilt" participants make many choices as they write their narratives: they must choose whether to reveal certain aspects of their history, of their reality, to subsidize the production of new knowledge.

Throughout the process of making the Quilt, its participants have several aesthetic experiences designed as openings to incite subjects to become aware of their histories and of their ability to choose, to make decisions on what to bring up and recount. The mobilization of internal resources to recover lived experiences, produce a written narrative and then transform it into an image enables participants to access their Sensibility, thus turning their experiences into a veritable work of art. In so doing, subjects may also become aware of their reflective faculty through art, going from an aesthetic awareness to an epistemological awareness as they have an opportunity to be authors, art makers and producers of knowledge.

\section{Methodology: a hermeneutical approach to (auto) biographical narratives}

Our study examines 46 narratives by Teacher Education undergraduate students from a private University located in the city of São Paulo's eastern area. Those narratives were created using "Quilt" during a course on "Organizing a Teacher's Work", March through June 2018. Data was gathered through a contextual questionnaire answered by all 46 participants. This study employed a qualitative approach that involved a contextual questionnaire featuring questions on what "Quilt" participants liked and did not like about their experience, and also asking them to choose three words to describe it. Our analysis of "Quilt" is based on the answers to that questionnaire.

Data were analyzed using a hermeneutic approach, after Gadamer (2000). The following concepts were engaged with: the circle of understanding, the relationship between part and whole, tradition, horizon and language. The hermeneutic approach holds that one must seek to understand the thoughts of the other and of the world, and subsequently to understand oneself. Almeida, 
Flickinger and Rohden (2000, p. 23) writes that "understanding means that I can think and ponder that which the other person thinks. [...] Therefore, understanding does not mean mastering what stands before us, nor the other or, generally speaking, the objective world".

A hermeneutic understanding of narratives assumes that "the person who wishes to understand a text is willing to allow that text to tell them something. For that reason, a hermeneutically-constituted consciousness must be willing to welcome alterity in a text." (ALMEIDA; FLICKINGER; ROHDEN, 2000, p. 145).

Hence, the act of understanding implies setting aside one's acquired history and conceptions so as to regard things from a different perspective. To that end, Gadamer stresses the importance of scientificity in hermeneutics when he explains that

by scientificity I mean objectiveness, and it is undoubtedly correct to exercise critical control over one's subjective, preconceived notions that play a part in the very act of observing. Therefore, as a matter of principle, scientific ascertainments must be intelligible and verifiable to anybody, and support the notion of objective knowledge (ALMEIDA; FLICKINGER; ROHDEN, 2000, p. 20).

Gadamer believes that our understanding of the world is mediated by language, which shapes us with reference to other people. As he considers everyone to be ideologically alienated, it follows that all formation is necessarily deformed, and thus "all language is, therefore, educational, formative or deformative" (ALMEIDA; FLICKINGER; ROHDEN, 2000, p. 196).

In Gadamer's (2000) hermeneutics, language also involves all that is left unsaid in narration. To him, language is the medium by which we discover our being-in-the-world: "It therefore reflects the potential of thought. [...] Each time someone searches for a word to 'express' what they are thinking, those thoughts become palpable not only to the listener but also to the speaker" (ALMEIDA; FLICKINGER; ROHDEN, 2000, p. 52).

The process of making the "Quilt" can be taken as language in its written, oral, and pictorial dimensions; it is a project of understanding some of the constitutive aspects of being. As the subject narrates their own story and sheds upon it the light of awareness, "Quilt" promotes reflection and enhances the subject's ability to view their own story from a different viewpoint, one of increased awareness of their place in the world and in relation to that world. 


\section{5 "Quilt": a bridge to connect sensitivity and reason in teacher Education}

Accessing delight/ discontentment aspects allows us to work with Josso's (2007) sensitive being. The relevance of accessing those feelings lies in its potential to help the future teacher gain a better understanding of both the human mind and the role of personal history in an individual's learning processes. To express this less technically, becoming aware of educational situations where one has experienced discontentment might predispose a future teacher to show more empathy and respect for students and their knowledge, as that teacher is able to better understand the consequences that words, acts and situations may have on a student's educational and/or personal trajectory.

Our "Quilt" participants were asked to state what they had liked best about the experience. Their answers were: $43 \%$ listening to other people's stories and learning with them $20 \%$ producing the pictorial narrative (the quilt squares), $17 \%$ the group's involvement on the project; $13 \%$ remembering their own story; $9 \%$ the movie $6 \%$ telling their story and presenting their hinge moments to the group.

The subjects' acknowledgement of the relevance of learning/hearing their colleagues' histories can be connected to Freire's (2005, p. 15) claim that awareness cannot be achieved by isolated individuals: "awareness is constituted as awareness-in-the-world". By virtue of being an aesthetic experience, making the "Quilt" must be regarded as an invitation to self-awareness in that it allows subjects to acknowledge themselves and the others as historical beings.

Such awareness involves the body, reason, sensation, emotions, and feelings as the subject endeavors to attribute meaning to their experiences. In view of that, we believe that the processes of a) regarding one's history differently, b) seeking to understand it, and c) possibly to resignify it promote the development of self-awareness, as the subjects progress from naïve curiosity to epistemological curiosity.

Participants' choices of different "Quilt" stages as the most important ones are in line with Freire's (2013) "ethical responsibility of being in the world", since that act of selection enabled students to recover their stories and to understand the structures underlying their education, which may pave the way for a different praxis on their part.

Each and every one of us is constantly connecting the various sensory dimensions, as is evidenced by some students having stated that the most important 
thing about their participation in "Quilt" was remembering their own story - we believe that remembering involves all senses, whether or not those are concrete processes.

The participants were also asked to state what they had liked least about their "Quilt" experience. Their answers were: $36 \%$ no dislikes, $17 \%$ dealing with their emotions, $11 \%$ exposing their story to the group, $11 \%$ delivering the presentation of their story (due to shyness), $6 \%$ the group's involvement on the project.

These figures attest that a significant part of the students claimed not to have experienced "discontentment". Moreover, all discontentment aspects cited by our study participants relate to Josso's "sensitive being", which automatically mobilizes all other beings, especially the "emotive being" and the "affective being".

It should be noted that most participants in this study have experienced an educational model in which the other is often not allowed to exist. This is manifest in their narratives concerning both school and their homes. For instance, among their High School memories the students highlighted several moments of being made to feel unworthy by their teachers, which makes us wonder about the paths those students will need to walk in order to disentangle themselves from the heavy chains formed during that period of their lives.

When she saw what I was doing, she yelled at me, ripped out the sheets from my notebook and told me to start over, and stood there watching me copy and cry, until finally the class ended (Madison Bridge, 2018).

He would say to me, "N., you can either learn or you can learn", slap the ruler against my desk and call me stupid! I'm tired of teaching! Your grade is zero. You'll never learn (Bridge of Sighs, 2018).

By asking students to tell their own stories and to listen to their colleagues', "Quilt" promotes the development of aspects such as those portrayed in the quotes above, because listening to others gives them an opportunity to resignify themselves by realizing that there may be different ways of regarding any experience. Therefore, the shared group experience becomes a moment of revelation about things that might have been taken as unshakeable truths for many years; the possibility of choosing an experience and sharing it with others provides an opening to resignify that fact, and consequently one's own history. 
Reflecting on language usage in school spaces and its impact on school relationships, Santamaria and Ade-Ojo (2019, p. 56) draw on Haworth's Bakhtin in the classroom: what constitutes a dialogue text? to remind us that all voices in a classroom produce not just knowledge but also identities. Therefore, the participation processes such as those comprised in the different stages of "Quilt" may involve a lot of anguish, because students are called to effectively cross that bridge and claim a speaking role.

As they are invited to tell their stories (either in writing, orally or by making the quilt squares), the students access a hitherto dormant world. This awakening is a result of the feelings and reflection involved in the aesthetic experience. This is in line with some of Freire's (2005) steps towards self-awareness:

as a humanist and liberating pedagogy, the pedagogy of the oppressed has two different moments. First, the oppressed unveil the world of oppression and commit themselves to transforming it via praxis; secondly, after the oppressing reality has been transformed, this pedagogy of the oppressed turns into a pedagogy of men in a process of continuous liberation (p. 46).

The two steps described by Freire (above) can be found in the work with autobiographical narratives promoted by "Quilt". We believe that as a participant writes their own story, they unveil both themselves and the world, followed by a transformation.

In order to glimpse what students had retained from the process of making the "Quilt", we asked each one of them to choose three words that they felt best described the experience. Their answers are presented in Table 1.

Table 1 - Words chosen by the students to define their participation in "Quilt"

\begin{tabular}{ll}
\hline Love & $21 \%$ \\
Gratitude & $19 \%$ \\
Union, reflection and overcoming & $17 \%$ \\
Learning and emotion & $10 \%$ \\
Respect, memories, empathy, and life stories & $8 \%$ \\
Family and freedom & $6 \%$ \\
Motivation, joy, feelings, emotions, caring for others, changes, knowledge & $4 \%$ \\
Faith, forgiveness, suffering, understanding, deep, and experience & $2 \%$ \\
\hline
\end{tabular}

Source: Authors (2020) 
We believe the descriptors in Table 1 to be directly related to Freire's (2013) concept of aesthetic curiosity, in that students' choice of words indicates that "Quilt" stirs sensations and feelings as it invites participants to contemplate and recount their own story or listen to/experience someone else's.

In a similar vein, it should be noted that even though "Quilt" was presented as a formative and investigative device during the course on "Organizing a Teacher's Work", students did not see it as a mere activity. The narratives made it clear that most of the group had grasped the intentionality underlying our educational action, which allowed us to delve deeper into matters related to the constitution of a teacher's professional identity. All "Quilt" stages involved aesthetic experiences, thus working towards Josso's (2007) claims that

the self-reflective practices promoted by written life stories focusing on one's formative years often function as laboratories to understand how we learn to live in an ever-changing world, a world unmastered in its totality but that may be partially mastered by individualities, a world that is ceaselessly making and unmaking itself and that defies the belief on an "acquired identity" in favor of an existentiality perennially in the making (p. 431).

Experiencing "Quilt" may therefore be regarded a bridge into a world of discoveries of the utmost importance to foster self-awareness and to the configuration of participants' professional praxis, given that "Quilt" offers both opportunities to learn and aesthetic experiences that may impact a teacher's professional identity.

Before I finish, I just want to thank you for this educational activity, it was full of sensibility, companionship, and love, it was an experience I'll always carry in my heart (...) it made me think about a lot of things (Suspension bridge, 2018).

As I said in my narrative, right after finishing High School I never thought that I would ever want to become a Preschool teacher, but life brings us experiences we hadn't lived yet and that ends up making us take a certain path. (Kintaikyo, 2018).

A better understanding of the inner workings of praxis and being can improve a subject's degree of self-awareness and allow them to act in a more effectively transformative manner. Therefore, by stirring a range of feelings and sensations that may increase the future teacher's self-awareness, the aesthetic dimension 
promotes the development of autonomy and emancipation, if the subjects are willing to participate in the experience.

\section{Final thoughts}

Throughout this study, we have argued that participating in the formative and investigative device called "Quilt" is an opportunity for students undergoing educational processes to become more self-aware. A key component of this process of self-reflection and listening to others is that it implies learning about oneself and about how a subject's identity is formed.

When the students are invited to recount their life stories, a latent aesthetic experience lies ahead of them: they have the chance to acknowledge the power of their existences and the importance of interaction in their environment. Among our research data, we were able to identify delight and discontentment aspects experienced by the students that might directly influence their professional praxis, regardless of their degree of awareness of those aspects. One possible result of such influence is the possibility of breaking away from what Josso (2007) refers to as the "existential fragmentation paradigm", in which emotions and affectivity are neglected in favor of an overrated cognitive dimension.

Given the scarcity of research on aesthetics and teachers' professional identity, we believe this study to be valuable. Berkenbrock-Rosito's (2009) device "Quilt" can be seen as a possible aesthetic path into self-awareness, particularly well-suited for future Education professionals because it promotes authorship over mere reproduction. The main goal of "Quilt" is to open aesthetic paths to autonomy and emancipation.

The making of the quilt can be regarded as a process of rousing self-awareness, a transition from aesthetic curiosity to epistemological curiosity, for "Quilt" participants are invited to look at their own story through art and to attribute meaning to their experiences using a combination of reason, bodily memories, feelings and emotions.

One may reasonably infer that participating in "Quilt" offers subjects an opportunity to perceive themselves as incomplete: as they produce their narratives and answer the questionnaires, the participants can presumably identify the chains each one of them must break to promote an Education that encourages autonomy and emancipation. This process may allow students to access and resignify their own experiences, thereby enrichening their future teaching praxis. 
The reflection that upholds the narratives of our research subjects is sparked by dialogue and listening. Those practices offer answers and questions on how to welcome the embodied subject, the epistemic subject; on how to create a space where people can talk about themselves, acknowledge their dreams, make decisions and, if needed be, break away from something - in short, spaces where people can act freely, in every sense of freedom, autonomy and emancipation applicable to aesthetic values within the early stages of a teacher's professional education. 


\section{"Colcha de Retalhos", experiência estética e narrativa autobiográfica: a arte da escuta na formação inicial docente}

\section{Resumo}

Este artigo tem como objetivo analisar o dispositivo formativo e investigativo "Colcha de Retalhos", uma metodologia e epistemologia desenvolvido por Berkenbrock-Rosito, desde 2001. Neste estudo, apresenta-se o dispositivo Colcha de Retalhos como proposta de formação inicial do professor por meio de Narrativas (Auto) Biográficas em suas dimensões escrita, pictórica e oral no Curso de Pedagogia de uma universidade privada na zona leste da cidade de São Paulo. Na metodologia da pesquisa foi utilizado um questionário contextual, que inclui perguntas sobre o que os participantes gostaram e o que não gostaram na realização da "Colcha de Retalhos". Os dados foram analisados, sob o enfoque hermenêutico, mostram a importância da "Colcha de Retalhos" como metodologia de escuta dos sujeitos, o que pressupõe a dimensão estética na constituição da identidade docente.

Palavras chave: Colcha de Retalhos. Experiência Estética. Formação inicial de Professores.

\section{"Colcha de retazos", experiencia estética y narrativa autobiográfica: el arte de la escucha en la formación inicial del docente}

\section{Resumen}

Este artículo tiene como objetivo analizar el dispositivo formativo y investigativo llamado "Colcha de Retazos", una metodología y epistemología desarrollada por BerkenbrockRosito, desde 2001. En este estudio, el dispositivo Colcha de Retazos, dentro del enfoque de la investigación autobiográfica, se presenta como una propuesta de formación inicial del docente por medio de narrativas en sus dimensiones escrita, pictórica y oral, en el Curso de Pedagogía de un área privada universitaria el lado este de la ciudad de São Paulo. En la metodología de la investigación fue utilizado un cuestionario contextual, en el cual se incluian preguntas referentes a la aceptación y recepción de los participantes con referencia a la realización de la "Colcha de Retazos". Los datos recopilados fueron analizados bajo el enfoque hermenéutico, indicaron la importancia de la "Colcha de Retazos" como una metodología de escucha de los sujetos, que presupone la dimensión estética en la constitución de la identidad docente.

Palabras clave: Colcha de Retazos. Experiencia Estética. Formación inicial de Docentes. 


\section{References}

ADORNO, T. W. Educação e emancipação. 2. ed. Rio de Janeiro: Paz e Terra, 2002.

ALMEIDA, C. L. S.; FLICKINGER, H.-G.; ROHDEN, L. (orgs.). Hermenêutica filosófica: nas trilhas de Hans-Georg Gadamer. Porto Alegre: EDIPUCRS, 2000.

BARROS, C. M. P.; DIAS, A. M I.; CABRAL, A. C. A. Ações de formação docente institucionais: quais as contribuições para a constituição do docente-bacharel? Ensaio: Avaliação e Políticas Públicas em Educação, Rio de Janeiro, v. 27, n. 103, p. 317-339, abr.jun. 2019. https://doi.org/10.1590/S0104-40362019002701476

BERKENBROCK-ROSITO, M. M. Colcha de retalhos: história de vida e imaginário na formação. Educação, Santa Maria, v. 34, n. 3, p. 487-500, set./dez. 2009. http://dx.doi.org/10.5902/19846444

FREIRE, P. À sombra desta mangueira. 11. ed. Rio de Janeiro: Paz e Terra, 2013.

FREIRE, P. Pedagogia da autonomia: saberes necessários à prática educativa. São Paulo: Paz e Terra, 1996.

FREIRE, P. Pedagogia do oprimido. 47. ed. Rio de Janeiro: Paz e Terra, 2005.

JOSSO, M.-C. A transformação de si a partir da narração de histórias de vida. Educação, Porto Alegre, v. 30, n. 3 (63), p. 413-438, set./dez. 2007.

JOSSO, M.-C. As figuras de ligação nos relatos de formação: ligações formadoras, deformadoras e transformadoras de vida. Educação e Pesquisa, São Paulo, v. 32, n. 2, p. 373-383, maio/ago. 2006. https://doi.org/10.1590/S1517-97022006000200012

MATURANA, H. Emoções e linguagem na educação e na política. Belo Horizonte: UFMG, 1998.

PERRISÉ, G. Estética \& educação. 2. ed. Belo Horizonte: Autêntica, 2014.

SANTAMARIA, M.; ADE-OJO, G. Vozes de outras pessoas: uma investigação reflexiva sobre o poder e a voz dentro da sala de aula e as implicações de pesquisar a própria prática. Ensaio: Avaliação e Políticas Públicas em Educação, Rio de Janeiro, v. 27, n. 105, p. 755-776, out./dez. 2019. https://doi.org/10.1590/S0104-40362019002702206 
SANTOS, L. R. Educação estética, a dimensão esquecida.

In: SANTOS, L. R. Educação estética e utopia política. Lisboa: Edições Colibri, 1995. P. 203-220.

SCHILLER, F. A educação estética do homem. São Paulo: Iluminuras, 2002.

\section{Information about the authors}

Margaréte May Berkenbrok-Rosito: Professor in the Post-Graduate Master's and Doctoral Program in Education and Professional Master's Program Training for Educational Managers at Universidade Cidade de São Paulo. Doctorate in Education at Universidade Estadual de Campinas, Brasil. Post-Doctorate in History of Education at Universidade de Lisboa, Portugal. Contact: margaretemay@uol.com.br

iD http://orcid.org/0000-0001-9010-1101

Juliana Paiva Pereira de Souza: Master in Education at Universidade Cidade de São Paulo. Educational Coordinator at Serviço Nacional de Aprendizagem Comercial (Senac). Contact: julianappereira@hotmail.com

iD https://orcid.org/0000-0002-2052-435X

Sidclay Bezerra Souza: Assistant Professor of Department of Psychology of the Faculdad de Ciências de la Salud - Universidad Católica del Maule, Chile. Post-doctor in Psychology at Universidade Federal de Pernambuco, Brasil. Ph.D and Master studies in Psychology Specialization in Educational Psychology (Faculdade de Psicologia, Universidade de Lisboa, Portugal). Contact: sbezerra@ucm.cl

iD https://orcid.org/0000-0003-3727-3793 